\title{
Fibropapillomatosis in immature Green Turtles (Chelonia mydas) from the Gulf of Venezuela
}

\author{
Fibropapilomatosis en juveniles de Tortuga Verde (Chelonia mydas) \\ del Golfo de Venezuela
}

\author{
Nínive Espinoza-Rodríguez ${ }^{1,2}$ (D) and Héctor Barrios-Garrido ${ }^{1,2,3}$ (D) \\ ${ }^{1}$ Grupo de Trabajo en Tortugas Marinas del Golfo de Venezuela. Maracaibo, Zulia, Venezuela. 'Laboratorio de Ecología General, \\ Centro de Modelado Científico (CMC), FEC, Universidad del Zulia. Maracaibo, Zulia, Venezuela. ${ }^{3}$ TropWATER-Centre of Tropical \\ Water and Aquatic Ecosystem Research, James Cook University. Townsville, Queensland, Australia. \\ Email: hbarriosg@fec.luz.edu.ve
}

\begin{abstract}
Fibropapillomatosis (FP) is affecting multiple marine turtle (MT) species worldwide. In Venezuela, the understanding about this neoplastic condition is still in early stage. Hence, this paper aims to assess the occurrence and frequency of FP in green turtles (GT) in the Gulf of Venezuela (GV). Herein, it was compiled and analyzed the reports in the database of the NGO 'Grupo de Trabajo en Tortugas Marinas del Golfo de Venezuela', which includes all records of stranded MT in the GV from 2000 to 2011. Between 2000 and 2006, in the GV only 2 cases of FP in MT had been reported (1.71\% of total records). Subsequently, between 2008 and 2011, encounters of FP were more frequent; resulting in a total of 7 immature GT ( $2.93 \%$ of the records) documented showing large masses or skin tumors in various parts of the body. The most affected area of the MT's body was neck and venous sinus $(37.50 \%)$, followed by the anterior flippers $(18.75 \%)$, plastron (18.75\%), posterior region (cloaca $18.75 \%$ ) and lastly, the eyes $(6.25 \%)$. All individuals presented two or more body areas with FP. Although a correlation between the presence of FP and environmental factors observed in the study area was not assessed, the turtles evaluated came from coastal waters with high levels of eutrophication, habitat degradation, and pollution. It is necessary to monitor the occurrence of this disease and the environmental factors that may negatively affect the survival of MT populations in the GV.
\end{abstract}

Key words: Marine turtle; green turtles; immature stage; herpes virus; Southern Caribbean
RESUMEN

Los fibropapilomas (FP) están afectando a múltiples poblaciones de TM a nivel mundial. En Venezuela, el conocimiento de esta condición neoplásica está todavía en etapas iniciales. El presente trabajo tuvo como objetivo evaluar la ocurrencia y frecuencia de aparición de FP en tortugas verdes (TV) en el Golfo de Venezuela (GV). Se compilaron y analizaron diversos reportes de la base de datos de la ONG 'Grupo de Trabajo en Tortugas Marinas del Golfo de Venezuela', la cual incluye todos los registros de TM varadas en el Golfo de Venezuela (GV) del 2000 al 2011. Entre los años 2000 al 2006, solo se habían reportado dos casos de FP en TM en el GV (1,71\% del total de registros). Seguidamente, entre los años 2008 y 2011, los encuentros de individuos con FP se hicieron más frecuentes, resultando en un total de 7 individuos inmaduros de TV $(2,93 \%$ de total de registros) documentados, que presentaron notables masas de tejido o tumores en varias partes del cuerpo. El área más afectada del cuerpo de las TM fueron el cuello y seno venoso $(37,50 \%)$, seguido por las aletas anteriores $(18,75$ $\%)$, plastrón (18,75\%), región posterior (18,75\%), y finalmente los ojos $(6,25 \%)$. Todos los individuos presentaron dos o más áreas del cuerpo afectadas con FP. A pesar que la relación entre la presencia de FP y las variables ambientales no se evaluó en esta investigación, según las observaciones directas de los ambientes donde provenían las tortugas afectadas, estos presentaban altos niveles de eutrofización, degradación de hábitat, y contaminación. Es necesario el monitoreo de la ocurrencia de esta enfermedad en el área y los factores ambientales que podrían estar afectando negativamente la sobrevivencia de las poblaciones de TM en el GV.

Palabras clave: Tortugas marinas; tortuga verde; estadio inmaduro; herpes virus; Caribe Sur 


\section{INTRODUCTION}

Fibropapillomatosis (FP) is a disease characterized by multiple cutaneous masses. This disease was first reported affecting marine turtles (MT) in the late 1930's years (yr), primarily affecting Green Turtles (GT) (Chelonia mydas). However, it has also been reported in loggerhead (Caretta caretta), olive ridley (Lepidochelys olivacea), hawksbill (Eretmochelys imbricata), leatherback (Dermochelys coriacea), and flatback (Natator depressus) turtles [20, 21, 22]. Depending on turtle size, the location and number of tumors can contribute to the animal weakening and eventually death [18].

It is known that tumors arise from a proliferation of epidermal cells (papillomas), dermal fibroblasts (fibromas), or both (fibropapillomas) $[1,20,30]$. Several studies of FP repeatedly point to an infectious etiology involving a virus or several viruses [22]. These viruses might be spread by biological vectors or may become more tumorigenic because of biotoxins [23]. FP is a widespread disease and its incidence and prevalence are mainly in shallow waters and coastal habitats where turtles apparently become infected with the infectious agent following movement to near-shore environments [1, 22].

In Venezuela, the incidence of FP has been poorly studied, mainly due to the difficulties to access to the number of localities where MT often nest and/or reproduce [12]. Balladares et al. [3] confirmed out of 391 stranding events throughout the Caribbean coast in Venezuela, only 20 MT with noticeable presence of FP tumors. Most records were from Zulia State, where only two cases were documented between 2000 and 2006 [24]. It is important to indicate that during those yr the monitoring program was not yet standardized and records were made in an opportunistic manner [4].

The Gulf of Venezuela (GV) is an important foraging ground for MT, mainly GT; this region is characterized by extensive seagrass beds, which allows turtles to feed, reproduce and develop [27]. In the GV, an extensive consumptive use (traditional and commercial) of MT, especially GT, had been documented [7, 8, 28]. This consumptive use could lead to a public health issue at local scale due to the common practice of consumption of turtle meat, blood, and oil (in some cases consumption of turtles visible infected with FP) by local fishers [4].

Here, it was compiled and summarized all information regarding immature GT with FP affectations found stranded and/or captured in the GV, in order to assess the occurrence and frequency of this disease in this important foraging ground Southern Caribbean.

\section{MATERIALS AND METHODS}

\section{Study area}

The GV is located on the north-western Caribbean coast of Venezuela. GV is positioned at the upper and exterior depression of the Maracaibo System (Latitudes $9^{\circ}$ and $12^{\circ} \mathrm{N}$, and Longitudes $70^{\circ} 15^{\prime}$ and $72^{\circ} 15^{\prime} \mathrm{W}$ ) between Zulia and Falcon States; next to Colombia and at the Southwest of Aruba, Bonaire and Curacao Islands (FIG. 1) [27]. It has a fluctuating water dynamic, and is considered a shallow water system, with depths between 20 to 30 meters $(\mathrm{m})$, temperatures from 28 to $30^{\circ} \mathrm{C}$, and salinity up to 35 practical units of salinity (UPS, by its Spanish acronym) [16, 17], and with an important upwelling area [29]. Also, GV includes a variety of habitats, from sandy beaches, mangroves forests, coral reef patches to extensive, highly productive seagrass beds $[25,27]$.

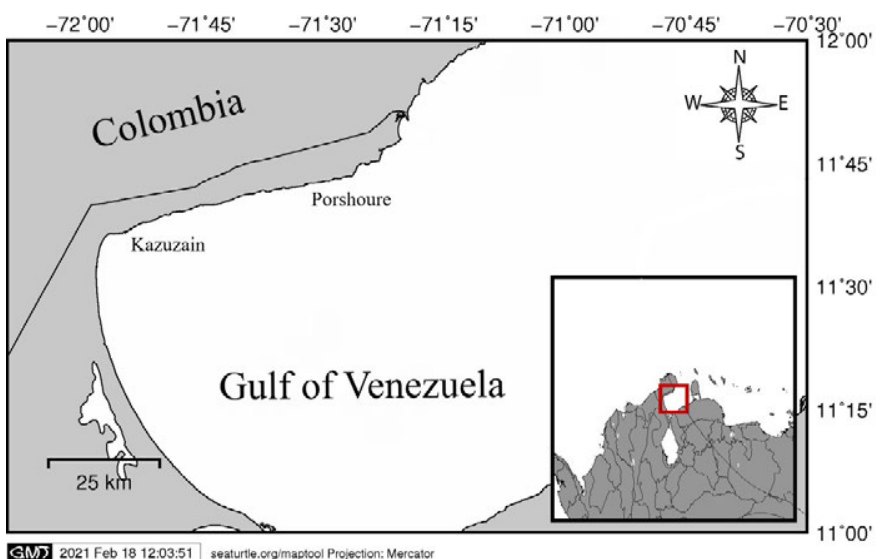

FIGURE 1. Study area. Gulf of Venezuela; indicating the locations where the individuals with fibropapillomatosis tumors were found and/or captured (Source: MapTool seaturtle.org)

\section{DATA COLLECTION AND ANALYSIS}

All data was compiled from 2008 to 2011, following the Opportunistic Notification Network (RAO, by its Spanish acronym) methodology, which is activated primarily by members of indigenous/ local communities that inhabit these coasts notifying the capture, stranding and/or direct observation of any MT its location, condition (dead or alive), and any other important remark to describe the case $[4,19]$. When a MT with noticeable tumors was encountered, "in situ" measures of carapace size (curved carapace length [CCL] and width [CCW]), weight (when possible), and the presence and location of tumors were documented [13, 15, 19].

The CCL was converted to Straight Carapace Length (SCL) using the equation described by Bjornal and Bolten [10] to calculate the Body Condition Index $\left(\mathrm{BCl}=\right.$ body mass $\left.\cdot \mathrm{SCL}^{-1}\right)$ of each turtle with FP [9]. It was also assigned to each turtle a Severity Score (SS) determined by the size and number of tumors: $0=$ non-diseased, 1 $=$ mildly afflicted, 2 = moderately afflicted and $3=$ severely afflicted $[2,11]$. It was determined the number of GT in each category (SS) at each capture and/or encounter site. A linear correlation between $\mathrm{CCL}$ and $\mathrm{BCl}$ in turtles with $\mathrm{FP}$ was also performed to evaluate this relationship [5].

\section{RESULTS AND DISCUSSION}

From 239 reported cases of stranded and/or captured MT throughout the Western coast of the GV from 2008 to 2011, only a total of 7 individuals $(2.93 \%)$ of immature GT were reported showing large masses or skin tumors in several parts of the body (FIG. 2); noticing an increase in the previous number of records to 9 specimens with evident FP tumors (merging records from 2000 to 2011).

Before 2007, MT with noticeable diseases such as FP were not easily encountered or found in the GV. There were only two cases registered between 2000 and $2006(1.71 \%$ of total records; $\mathrm{BCl}=$ 0.63; category 1) [24]. From 2008 to 2011 monitoring and evaluation of diseases in the area increased significantly, recording a total of 7 new confirmed cases of FP in sea turtles from the GV $[15,19]$. 


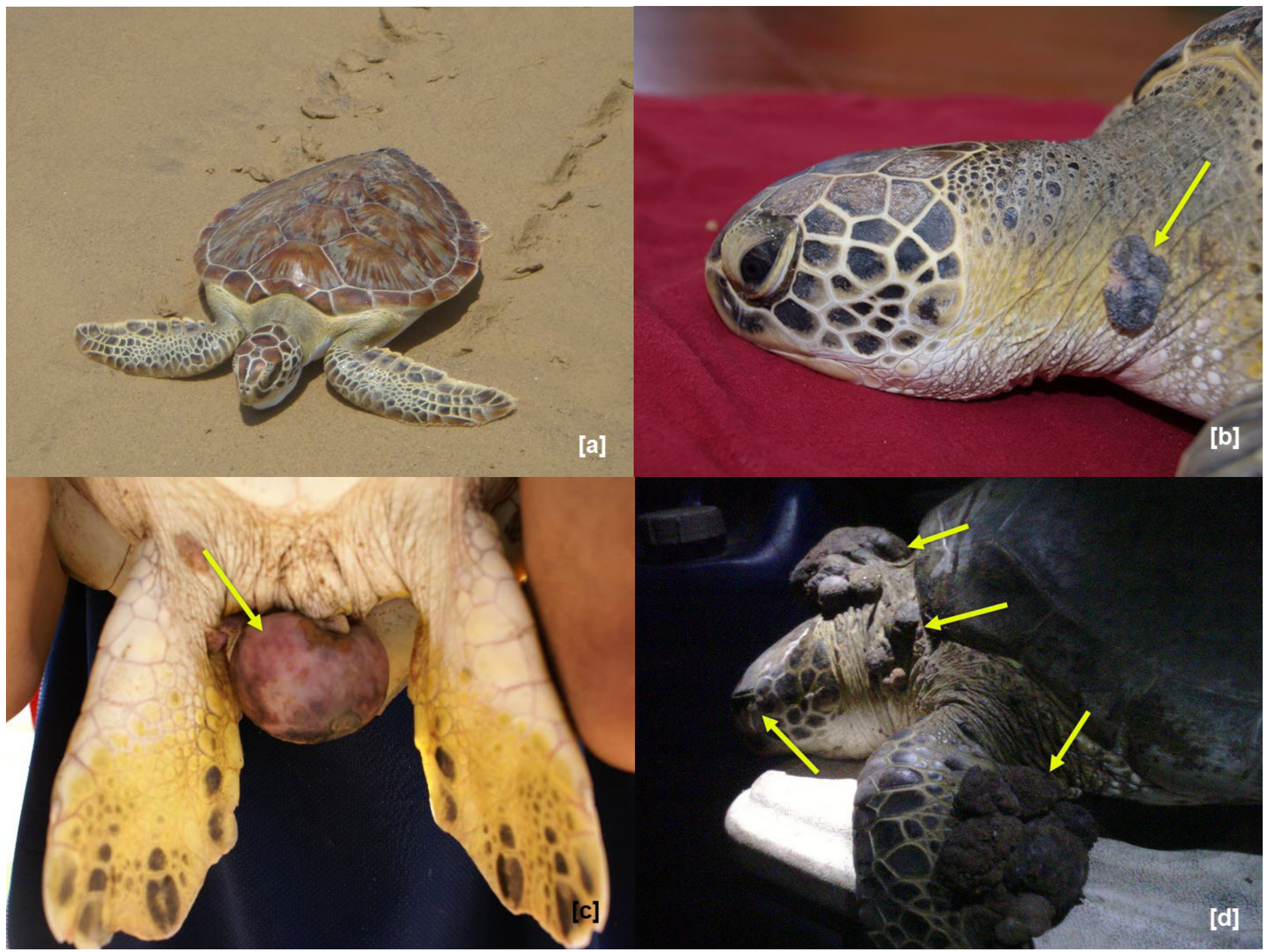

FIGURE 2. Green Sea Turtles captured in the Gulf of Venezuela with Fibropapillomatosis (arrows indicate skin tumors), its body location and categories of tumor severity $(0=$ non-diseased [a], $1=$ mildly afflicted [b], $2=$ moderately afflicted [c] and 3 = severely afflicted $[\mathrm{d}]$ )

FP is considered a threat to GT populations worldwide, mainly due to its prevalence and severity $[11,22]$. Overall, most MT with FP evaluated were immature (85.7\%), with CCL larger than 35 centimeters $(\mathrm{cm})$, which correspond to findings in Florida, Hawaii, Brazil and Australia [2, 11, 14]. Previous research has proposed two potential explanations for the presence of FP in smaller (i.e. younger) turtles, as these individuals are exposed to the virus and several stressors associated with migration upon recruitment to neritic zones, which indicates a horizontal transmission. These stressors also might enhance the emergence of tumors and FP lesions in latently infected turtles [22]. Direct transmission may also be occurring between co-habiting turtles via interactions such as mating and aggression $[20,22]$. The GV is known to be a recruiting and development area for MT, specifically, the GT population in the GV includes individuals from many rookeries throughout the Caribbean (such as Florida, México, Colombia, Costa Rica, Nicaragua, Isla de Aves [Venezuela], among others) [6] with a large number of immature individuals, hence resulting the most affected size category.

All assessed individuals were by catch from diverse artisanal fishing gears (mostly artisanal trawling nets). Body distribution of tumors (FIG. 3) was analyzed for all 7 turtles. The anterior region of the body was the most affected (37.50 \% neck and venous sinus, $18.75 \%$ anterior flippers), followed by plastron (18.75\%), posterior region (cloaca $18.75 \%$ ) and eyes (6.25\%). All individuals presented two or more body areas with FP.

As mentioned before, a larger percentage of tumors were observed in the anterior region of the MT's body $(37.50 \%$ neck and venous sinus, $18.75 \%$ anterior flippers). All individuals presented two or more body regions with $\mathrm{FP}$, an observation also noted in studies from Florida and Hawaii [18]. According to the body distribution of these tumors, several studies indicate that external FP sometimes regress if the turtle can maintain its body condition, and also, can be treated 


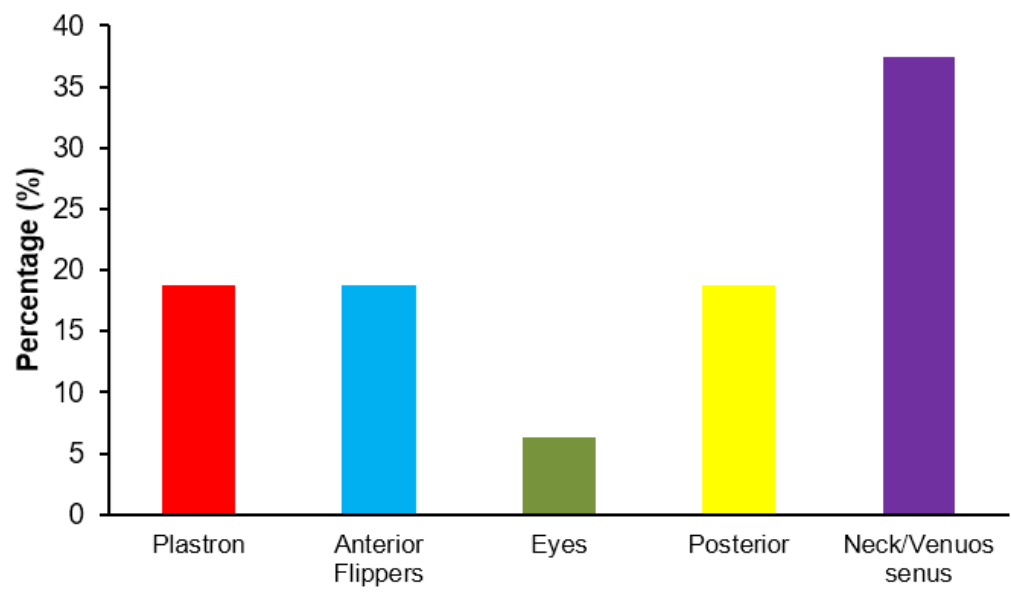

FIGURE 3. Body distribution of large masses or skin tumors on Green Sea Turtles captured in the Gulf of Venezuela

if there are enough personnel and equipment to do so (treatments include surgical tumor removal and secondary care for debilitation) [26]. When the tumors affect the eyes and/or mouth, preventing the turtle from foraging effectively, they can lead to death from starvation. Additionally, internal tumors are particularly devastating and often overlooked when working on-site [32].

Six captured turtles with FP were registered in one locality (Kazuzain port). The average CCL was $34.7 \mathrm{~cm}(\mathrm{SD}=6.74 \mathrm{~cm}$; Range 25.5 to 48.5 ) and the mean weight was $5.28 \mathrm{Kg}$ (SD = $2.23 \mathrm{Kg}$; Range 1.8 to 5.9). All turtles were considered immature or juvenile (85.7\%). Only one turtle was found at another location (Porshoure port), which measured $61.9 \mathrm{~cm}$ CCL and had a tumor severity of the highest ranking (category 3 ). The individuals from Kazuzain presented a moderately afflicted condition (category 2 ) with $71.4 \%$ of the total cases (FIG. 2).

MT body condition index ranged between 0.07 and 0.19 . Due to the few records of turtles with FP evaluated, it was not possible to determine a significant relationship between curved carapace length, body condition index and the presence of FP in MT in the GV.

Several researchers $[1,11,18]$ in the Eastern United States, Dos Santos et al. [14] in Brazil, and Van Houten et al. [31] in Hawaii have supported the argument that the occurrence and prevalence of FP are associated with coastal areas highly or moderately polluted, with high human population density, agricultural and urban runoff, sewage and/or high production of algal biotoxins. For this reason, MT are often used as a sentinel species due to their high public profile and vulnerability to degradation of the environmental health of the ecosystem [1, 22]. Although a correlation between the presence of FP and environmental factors observed in the study area was not assessed, the turtles evaluated came from coastal waters with high levels of eutrophication, habitat degradation, and pollution, which could have increased due to high precipitations during the sampling period $[15,16]$. However, it is necessary to monitor environmental factors variations and/or fluctuations that can negatively affect the survival of MT populations in the GV.

\section{CONCLUSIONS}

Tumors or large skin masses related to FP were significantly noticeable from 2008 to 2011 in the immature GT from GV. Indeed, turtles with evident tumors increased from $1.71 \%$ (between the years $2000-2006$ ) to $2.93 \%$. Soft tissues presented in the anterior area, such as neck, venous sinus, and anterior flippers showed to be the most affected (from $37.50 \%$ to $18.75 \%$ of the cases recorded).

The study of MT diseases from populations in the coast of Venezuela is relatively scarce. It is necessary the assessment of the different diseases, their occurrences, dynamics, and frequency, and keep monitoring their trends over the $\mathrm{Yr}$. These strategies will help on the better understanding of their implications over the MT populations that inhabit these coasts. In the GV, there is now a first in-depth approach on comprehending the occurrence and frequency of FP in immature individuals of GT.

\section{ACKOWLEGMENTS}

The acknowledge to the local monitors, members, and volunteers of the NGO Grupo de Trabajo en Tortugas Marinas del Golfo de Venezuela (GTTM-GV) for all their support in the field, their assistance and perseverance working within the Red de Aviso Oportuno (RAO-Zulia). Thanks also to Venezuela's Ministry of Eco-Socialism and Water (Zulia State's Environmental Office), and Public Ministry (Environmental Office No. 28) for their assistance in the treatment of these specimens and the granted permit. Thanks to the assistants, professors, and students of the Laboratory of General Ecology, from the Department of Biology of the Experimental Faculty of Sciences at the University of Zulia and other NGOs who collaborated during the sampling period. 


\section{BIBLIOGRAPHIC REFERENCES}

[1] AGUIRRE, A.; LUTZ, P. L. Marine Turtles as Sentinels of Ecosystem Health: Is Fibropapillomatosis an indicator?. EcoHealth 1: 275-283. 2004.

[2] BALAZS, G.H. Current status of fibropapillomas in the Hawaiian green turtle, Chelonia mydas. In: Research plan for marine turtle fibropapilloma. Balazs, G.H.; Pooley, S.G. (Eds.). U.S. Dep. Commer., NOAA Tech. Memo. NMFSSWFSC-156., Pp. 47-57. 1991.

[3] BALLADARES, C.; MARÍN, E.; ESPINOZA-RODRÍGUEZ, N.; BARRIOS-GARRIDO, $\mathrm{H}$. Prevalence of fibropapillomatosis on stranded sea turtles in the Venezuelan coast. Rev. Bio Cien. 4 (4): 04.04.02. 2017. http://dx.doi.org/10.15741/revbio.04.04.02.

[4] BARRIOS-GARRIDO, H. Socio-economic drivers affecting marine turtle conservation status: Causes and consequences. College of Science and Engineering, James Cook University. Townsville, Australia. Thesis of Grade. 287 pp. 2018. https://doi. org/10.25903/5beOfecec8548.

[5] BARRIOS-GARRIDO, H.; ESPINOZA-RODRÍGUEZ, N.; SHIMADA, T.; WILDERMANN, N. Body condition index in rescued Green turtles (Chelonia mydas) in the Gulf of Venezuela: a seven year assessment. Proceedings of the Thirty-Fifth Annual Symposium on Sea Turtle Biology and Conservation, Dalaman, 18-24 April 2015. Turkey. 17 pp. 2015.

[6] BARRIOS-GARRIDO, H.A.; BECKER, P.; BJORNDAL, K. A.; BOLTEN, A.B.; DIEZ, C.; ESPINOZA-RODRÍGUEZ, N.; FASTIGI, M.; GRAY, J.; HARRISON, E.; HART, K.A.; MEYLAN, A.; MEYLAN, P.; MONTIEL-VILLALOBOS, M.G.; MORALES, F.; NAVA, M.; PALMAR, J.; PETIT-RODRIGUEZ, M.J.; RICHARDSON, P.; RODRÍGUEZ-CLARK, K.M.; ROJASCAÑIZALES, D.; SANDOVAL, M.G.; VALVERDE, R.A.; VAN DAM, R.; WALKER, J.T.; WILDERMANN, N.; HAMANN, M. Sources and Movements of Marine Turtles in the Gulf of Venezuela: Regional and Local Assessments. Reg. Stud. Marine Sci. 36: (101318): 1-8. 2020. https://doi.org/10.1016/j. rsma.2020.101318.

[7] BARRIOS-GARRIDO, H.A.; ESPINOZA-RODRÍGUEZ, N.; ROJAS-CAÑIZALES, D.; PALMAR, J.; WILDERMANN, N.; MONTIEL-VILLALOBOS, M.G.; HAMANN, M. Trade of Marine Turtles along the Southwestern Coast of the Gulf of Venezuela. Marine Biodivers. Rec. 10(1): 1-12. 2017. https://doi.org/10.1186/ s41200-017-0115-0.

[8] BARRIOS-GARRIDO, H.A.; PALMAR, J.; WILDERMANN, N.; ROJAS-CAÑIZALES, D.; DIEDRICH, A.; HAMANN, M. Marine Turtle Presence in the Traditional Pharmacopoeia, Cosmovision, and Beliefs of Wayuú Indigenous People. Chelonian Conserv. Biol. 17(2): 177-186. 2018. https://doi.org/10.2744/CCB-1276.1.

[9] BJORNDAL, K.A.; BOLTEN, A.B.; CHALOUPKA, M.Y. Green turtle somatic growth model: evidence for density dependence. Ecol. Applicat. 10: 269-282. 2000.

[10] BJORNDAL, K.A.; BOLTEN, A.B. Comparison of straight-line and over-the-curve measurements for growth rates of green turtles, Chelonia mydas. Bull. Marine Sci. 45: 189-192. 1989.

[11] BORROWMAN, K. Prevalence and severity of fibropapillomatosis in juvenile green turtles (Chelonia mydas) in three habitats on
Florida's east coast. University of Central Florida, Orlando, Florida. Thesis of Grade. 59 pp. 2008.

[12] BUITRAGO, J.; VERA, V.J.; GARCÍA-CRUZ, M.A.; MONTIELVILLALOBOS, M.G.; RODRÍGUEZ-CLARK, K.M.; BARRIOSGARRIDO, H.; PEÑALOZA, C.L.; GUADA, H.J.; SOLÉ, G. Tortuga verde, Chelonia mydas. En: Libro Rojo de la Fauna Venezolana. Rodríguez, J.P.; García-Rawlins, A.; Rojas-Suárez, F. (Eds.) 4ta Ed. Provita y Fundación Empresas Polar, Caracas, Venezuela. 4 pp. 2015.

[13] CONDE, B.; PALMAR, J.; ALVARADO, M.C.; ILUKEWITSCH, V.; MAVARES, M.; CAMACHO, J.E.; BARRIOS-GARRIDO, H.; ESPINOZA, N. Clinical and post mortem findings of a Green turtle (Chelonia mydas) captured in the Gulf of Venezuela. Proceedings of the Thirty-Second Annual Symposium on Sea Turtle Biology and Conservation. Huatulco, 11 - 16 March 2012. México. Pp. 27. 2012

[14] DOS SANTOS, R.G.; SILVA-MARTINS, A.; BAPTISTOTTE, C.; DA NÓBREGA-FARIAS, J.; WORK, T.M.; TOREZANI, E.; ANTUNES-HORTA, P.; BALAZS, G.H. Relationship between fibropapillomatosis and environmental quality: a case study with Chelonia mydas off Brazil. Dis. Aquatic Organisms. 89: 87-95. 2010. https://doi.org/10.3354/dao02178.

[15] ESPINOZA-RODRÍGUEZ, N.; BARRIOS-GARRIDO, H. Fibropapillomatosis in juvenile green turtle (Chelonia mydas) captured in the Gulf of Venezuela: Frequency associated with environmental conditions?. Proceedings of the Thirty-first Annual Symposium on Sea Turtle Biology and Conservation. NOAA Technical Memorandum NMFS-SEFSC-631. San Diego, 10 - 16 April 2011. USA. Pp.203. 2012.

[16] ESPINOZA-RODRÍGUEZ, N.; MORAN, L.; PERNÍA, Y.; WILDERMANN, N.; BARRIOS-GARRIDO, H. Fluctuaciones anuales y espaciales de factores fisicoquímicos en aguas superficiales de la costa nor-occidental del Sistema de Maracaibo: años 2009 - 2010. Memorias del Congreso. IX Congreso Venezolano de Ecología. Nueva Esparta, Venezuela. 21 al 25 de Noviembre 2011. Pp. 582. 2011.

[17] FEBRES, G.; MASCIANGIOLI, P. Hidrografía del Sistema de Maracaibo. En: El Sistema de Maracaibo. Rodríguez, G. (Ed.). Instituto Venezolano de Investigaciones Científicas (IVIC) Caracas-Venezuela. Pp. 33-59. 2000.

[18] FOLEY, A.; SCHROEDER, B.; REDLOW, A.E.; FLICK-CHILD, K.; TEAS, W. Fibropapillomatosis in stranded Green Turtles (Chelonia mydas) from the eastern United States (1980 - 98): trends and associations with environmental factors. J. Wildlife Dis. 41(1): 29-41. 2005.

[19] GRUPO DE TRABAJO EN TORTUGAS MARINAS (GTTMGV). Proyecto de Conservación de Tortugas Marinas en el Golfo de Venezuela, Reporte Anual. Maracaibo, Venezuela. 5 pp. 2012.

[20] HERBST, L.H. Fibropapillomatosis of marine turtles. Ann. Rev. Fish Dis. 4: 389-425. 1994

[21] HUERTA, P.; PINEDA, H.; AGUIRRE, A.; SPRAKER, T.; SARTI, L.; BARRAGAN, A. First confirmed case of fibropapilloma in a leatherback turtle (Dermochelys coriacea). Proceedings of the Twentieth International Sea Turtle Symposium. U.S. Dep. Commer., NOAA Tech. Memo. NMFS-SWFSC-477.Florida, USA. February 29th to March 4th, 2000. Pp. 193. 2002. 
[22] JONES, K.; ARIEL, E.; BURGESS, G.; READ, M.A review of fibropapillomatosis in Green turtles (Chelonia mydas). The Vet. J. 212: 48-57. 2016. http://dx.doi.org/10.1016/j.tvjl.2015.10.041.

[23] LANDSBERG, J.H.; BALAZS, G.H.; STEIDINGER, K.A.; BADEN, D.G.; WORK, T.M.; RUSSEL, D.J. The potential role of natural tumor promoters in marine turtle fibropapillomatosis. J. Aquatic Anim. Health. 11: 199-210. 1999.

[24] MONTIEL-VILLALOBOS, M.G.; BARRIOS-GARRIDO, H.; RIVERO, L. New report of Fibropapillomatosis in a subadult of Green Turtle in the Gulf of Venezuela. Proceedings of the Twenty-seventh Annual Symposium on Sea Turtle Biology and Conservation. NOAA Technical Memorandum NMFSSEFSC-569. Florida, 22nd to 28th February 2007. USA. Pp. 24. 2008.

[25] MORÁN, L.; SEVEREYN, H.; BARRIOS-GARRIDO, H. Moluscos bivalvos perforadores de rocas coralinas submareales de la alta Guajira, Golfo de Venezuela. Intercien. 39(2): 136-139. 2014.

[26] PHELAN, S.M.; ECKERT, K.L. Procedimientos para Atender Traumas en Tortugas Marinas. Red de Conservación de Tortugas Marinas del Gran Caribe (WIDECAST). Informe Técnico No. 4.71 pp. 2006.

[27] RODRÍGUEZ, G. Fisiografía del Sistema de Maracaibo. En: El Sistema de Maracaibo. Rodríguez, G. (Ed.) Instituto Venezolano de Investigaciones Científicas (IVIC) Caracas, Venezuela. Pp. 7-20. 2000.
[28] ROJAS-CAÑIZALES, D.; ESPINOZA-RODRÍGUEZ, N.; PETITRODRÍGUEZ, M.J.; PALMAR, J.; MEJÍAS-BALSALOBRE, C.; WILDERMANN, N.; BARROS, T.; BARRIOS-GARRIDO, $\mathrm{H}$. Marine turtle mortality in a southern Caribbean artisanal fishery: a threat for immature green turtles. Reg. Stud. Marine Sci. 38(101380): 1-7. 2020. https://doi.org/10.1016/j. rsma.2020.101380.

[29] RUEDA-ROA, D.T.; MULLER-KARGER, F.E. The southern Caribbean upwelling system: Sea surface temperature, wind forcing and chlorophyll concentration patterns. Deep Sea Research. Part I. Ocean. Res. Papers. 78: 102-114. 2013. https://doi.org/10.1016/j.dsr.2013.04.008

[30] SMITH, G.M.; COATES, C.W. Fibro-epithelial growths of the skin in large marine turtles Chelonia mydas (L.). Zoolog. 23: 93-98. 1938.

[31] VAN HOUTAN, K.; HARGROVE, S.; BALAZS, G.H. Land use, macroalgae, and tumor-forming diseases in Marine Turtles. PLoS ONE. 5(9): e12900. 2010. https://doi.org/10.1371/journal. pone.0012900.

[32] WORK, T.; BALAZS, G.H.; SCHUMACHER, J.L.; MARIE, A. Epizootiology of spirorchiid infection in green turtles (Chelonia mydas) in Hawaii. J. Parasitol. 91(4): 871-876. 2005. 